\title{
MEDIACIÓN Y ACUERDOS REPARATORIOS \\ EN LA METAMORFÓSICA JUSTICIA PENAL DEL SIGLO XXI*
}

\author{
MEDIATION AND REPARATORY AGREEMENTS \\ IN THE METAMORPHOSIS OF CRIMINAL JUSTICE \\ OF 21st CENTURY
}

\section{Silvia BARONA VILAR**}

RESUMEN: El siglo XXI ha supuesto la consolidación del sistema acusatorio en la mayor parte de los países occidentales. Este sistema no solo comporta un cambio de norma, sino también un cambio de cultura procesal. En esa nueva cultura se han incorporado procedimientos que permiten los acuerdos y pactos; por ejemplo, en unos casos con el Ministerio Público, como sucede con las conformidades; en otros, acuerdos entre víctima $\mathrm{y}$ victimario, que permiten trabajar desde y con las personas, y favorecen la reparación. En un panorama de ultrapunitivismo, la justicia restaurativa y la mediación, como cauces que favorecen el diálogo, se presentan como un retorno a las personas, una bocanada de aire fresco.

Palabras clave: justicia restaurativa, mediación, víctimas, acuerdos, reparación.
ABSTRACT: The 21st century has signified the consolidation of the accusatory system in most of western countries. This system not only involves a change of norm, but also a change in procedural culture. In this new culture, procedures allowing agreements and negotiations have been incorporated; for example, in some cases with the Public Prosecuter as it happens with plea-bargaining; in others, agreements between victim and victimizer, which allow working with people and favor reparation. In our current ultrapunitivism panorama, restorative justice and mediation - as instruments that favor dialogue - are presented as a return to people, a breath of fresh air.

Keyzords: Restorative fustice, Mediation, Victims, Agreements, Reparation.

* Artículo recibido el 10 de enero de 2018 y aceptado para su publicación el 22 de agosto de 2019.

** ORCID: 0000-0002-2140-5838. Directora del Grupo de Investigación de Excelencia MedArbValencia y presidenta de la Corte de Arbitraje y Mediación (Cámara Valencia). Catedrática de derecho procesal de la Universitat de València, con más de 600 publicaciones (20 libros de autoría única y 18 libros como editora), 18 tesis doctorales dirigidas, vinculaciones internacionales, tres veces doctora honoris causa, becaria de la Fundación Alexander von Humboldt y profesora invitada en numerosas universidades del mundo. Correo electrónico: silvia.barona@uv.es.

Boletín Mexicano de Derecho Comparado, nueva serie, año LI, núm. 155, mayo-agosto de 2019, pp. 685-720. 
SumARIO: I. Mediación penal, del deseo a la realidad. II. Contexto en el que se integra la mediación penal: quiebre del paradigma de justicia penal y reprogramación de la justicia neomoderna. III. Modelo restaurativo, una bocanada de aire fresco ante tanta expansión neopunitivista. IV. Elementos que componen la arquitectura de la mediación penal. V. ¿Limites objetivos y subjetivos para la mediación penal?

VI. Clases de mediación penal. VII. Conclusiones. VIII. Bibliografia.

\section{MEDiACiÓN PENAL, DEL DESEO A LA REALIDAD}

En 1936 se publicaba en España la obra poética de Luis Cernuda La realidad y el deseo, ésta conjugaba precisamente los dos componentes que intitulan este apartado y que nos permiten emplearlos, si bien alterándolos, al entender que, en la institución que abordamos se ha ido pasando de lo que en los años venideros fue un deseo a lo que en el sistema procesal penal acusatorio actual es ya una realidad.

La incorporación en los ordenamientos jurídicos de la mediación penal, como procedimiento instrumental - no alternativo, sino complementario del proceso penal, a través del cual se puede desarrollar la justicia restaurativa con intervención activa de víctima y victimario para alcanzar los fines preventivo, resocializador y restaurativo del sistema penal- no ofrece duda alguna en la actualidad, si bien es indudable que no es suficiente - aunque es loable - la mera incorporación legal de la institución en los sistemas jurídicos, por cuanto se requiere un cambio de cultura procesal penal, una transformación en el empleo de los instrumentos de tutela por los operadores jurídicos y una metamorfosis en la justicia penal. Demasiados siglos de una práctica procesal, seguida a lo largo de los tiempos, que ha propiciado una "crisis" que, lejos de ser sencilla, comporta resistencias, en algunos casos caos, si bien estamos convencidos de que el resultado no puede sino ser lo que Nietzsche denominaba como "la estrella fugaz", tras "el caos dentro de sí".

Hemos asistido a lo largo del siglo XX a numerosos proyectos de incorporación de la mediación penal; proyectos que permitían avizorar cambios en la sociedad occidental, amén de buscar mecanismos que favorecieran la tutela de las personas, la visibilidad de las víctimas, el tratamiento más humano de los presuntos delincuentes y la posibilidad de su resocialización. En ese itinerario se empleó como banco de pruebas, en la mayor parte de los sistemas jurídicos, la criminalidad juvenil, incorporando proyectos pilo-

Esta obra está bajo una Licencia Creative Commons

Atribución-NoComercial-SinDerivar 4.0 Internacional, IIJ-UNAM.

Boletín Mexicano de Derecho Comparado, núm. 155, mayo-agosto de 2019, pp. 685-720. 
to de mediaciones entre víctimas y menores presuntamente autores de los hechos delictivos. ${ }^{1}$

Un verdadero laboratorio de pruebas que presentó resultados positivos y favoreció la imparable incorporación de estos instrumentos en sede penal. La mediación penal se incorporaba como medio complementario del proceso penal, favorecía acuerdos que suponían una reducción de la consecuencia jurídico-penal, la mayor satisfacción de las víctimas (no solo por una posible indemnización, sino también por la reparación personal, e incluso moral, que en muchos casos se alcanzaba) y, como efecto-consecuencia, la sociedad percibía estos métodos como una suerte de desconflictivización social, de reducción de la potencial criminalidad al favorecer la reinserción social de los condenados, amén de garantizar una reducción de gastos, lo que era ya una constante en esa búsqueda imparable y esencial de "eficiencia" del modelo jurídico procesal penal.

En esta evolución, empero, no todo fue pacífico. Antes, la resistencia del pensamiento procesal penal petrificado se instalaba en una constante percepción de obstáculos a la incorporación de la mediación penal. Se hablaba de la posible quiebra de la presunción de inocencia, de la privatización de la justicia, de la violación del principio irrefutable del ius puniendi estatal, de la imposibilidad de pactar la consecuencia jurídica, de la afirmación de que el proceso penal no está para garantizar a las víctimas, sino a la sociedad, y un largo etcétera. Las resistencias no se vencieron fácilmente. Y prueba de ello fue que su incorporación ha sido paulatina, e inicialmente vinculada a proyectos piloto.

Ahora bien, la realidad ha estado venciendo al deseo. La incorporación de la mediación penal se produce en el marco de una transformación en profundidad de los sistemas jurídico-procesales penales; esto es, hablar de mediación no es referirnos a una institución que emerge de forma aislada e independiente, sino un cauce que se explica en un "todo" jurídico, ${ }^{2}$

1 Se pueden ver los proyectos de mediación en la justicia penal juvenil de diversos países (España, Estados Unidos, Gran Bretaña, Países Escandinavos, Francia, Alemania, Portugal, Brasil y Chile) en la obra colectiva de Barona Vilar (2009), referida toda ella a plantear la situación en la primera década del siglo XXI en torno a la incorporación de manifestaciones de justicia restaurativa, y esencialmente a la incorporación de la mediación penal en la justicia penal juvenil.

2 De ahí que Braithwaite (2003: 1), considerado como uno de los padres de la justicia restaurativa, defendiera que, con ella se está ante un nuevo estilo de vida, un camino para transformar el sistema legal en su conjunto, nuestra conducta y la manera de actuar de los 
en un sistema procesal diverso, con unos principios que exigen el "repensamiento" procesal y son los que han propiciado la metamorfosis de la justicia penal. ${ }^{3}$ Una metamorfosis que tenía un componente nuclear, la necesidad de colocar como eje del ordenamiento a la persona, integrar a quienes se ven afectados directamente por la comisión de los hechos delictivos - las víctimas, las grandes olvidadas del sistema - y descosificar a los presuntos autores de los hechos delictivos, incorporando unas garantías y el reconocimiento de los derechos fundamentales del detenido, preso o condenado.

En algunos países, como en México, la transformación de la justicia fue incluso consecuencia de reformas constitucionales, que exigían cambios jurídicos procesales de envergadura, como sucedió con la reforma constitucional mexicana del 18 de junio de 2008. Esos cambios que se fueron produciendo en las últimas décadas del siglo XX y también del XXI han supuesto una revolución del pensamiento procesal penal.

Ahora bien, no basta con cambiar las normas jurídicas, que es lo que realmente se ha venido produciendo, sino que es imprescindible transformar las mentes jurídicas, el pensamiento procesal para poder poner en práctica esta nueva cultura del proceso penal, que se inspira en una búsqueda de mayores garantías para las personas, una recuperación de la víctima, un tratamiento adecuado al sujeto pasivo del proceso, una necesidad de transparencia ante la sociedad y una absoluta necesidad de capacitación de los operadores jurídicos que deben poner en práctica este nuevo pensamiento procesal. Todo ello no se alcanza solo con una norma. Se requiere tiempo y presupuesto, dado que es fundamental formar buenos profesionales que desempeñen su función y también lo es el contar con equipos humanos capacitados en la judicatura para el nuevo código, sistemas informáticos interconectados (judicatura-fiscalía-policía), medios materiales como espacios adecuados, y por todo ello se requiere de concienciación política para que el sistema funcione.

políticos; un proyecto que es considerado intelectual y político, encaminado a actuar frente a lo que él ha denominado la "injusticia preventiva".

3 La mediación penal es el instrumento de incorporación de la mirada restaurativa, una mirada que inocula nuevos elementos en la justicia penal, nuevos postulados, que llevan a repensar la justicia penal. A propósito de esta idea, véase Barona Vilar (2018: 224), para referir la importancia que en este repensamiento ha tenido la incorporación, no sin resistencias, de la reparación en el sistema penal.

Esta obra está bajo una Licencia Creative Commons

Atribución-NoComercial-SinDerivar 4.0 Internacional, IIJ-UNAM.

Boletín Mexicano de Derecho Comparado, núm. 155, mayo-agosto de 2019, pp. 685-720. 
Es precisamente en este modelo procesal acusatorio en el que se incorporan instrumentos complementarios del proceso penal, entre otros, e instituciones que favorecen acuerdos, reducciones del proceso, que hacen visibles a las víctimas y que favorecen manifestaciones del principio de oportunidad que eran negados históricamente en el proceso penal. Se hace visible el consentimiento de las personas — víctimas y victimarios-, en unos casos para aceptar o pactar la pena, como sucede con la conformidad, y en otros para abrir el diálogo entre las personas, en aras de construir una sociedad menos agresiva y menos revanchista, pero con el cumplimiento de los fines del sistema penal. Probablemente lo que se produce es un cambio en el modus operandi de la justicia penal. Durante siglos, la justicia penal fue polarizada unilateralmente en torno a la noción de castigo, y el proceso se convirtió en un monólogo basado en el interrogatorio del imputado, de la víctima y de los testigos. Todo orientado unidireccionalmente al castigo del culpable y al mantenimiento de las normas, sirviendo de intimidación al culpable y al resto de potenciales candidatos al delito, ofreciendo, como señala Ríos Martín (2008: 20), una manera de calmar la sed de retribución.

La incorporación del diálogo y los encuentros personales abren una nueva manera de afrontar esta realidad, sin perjuicio de truncar los fines preventivos y retributivos, amén de resocializadores del modelo. Pero se introduce un componente restaurativo que abre esperanzas en las personas, una mirada diversa en la que la comunicación, el diálogo, la escucha están presentes. Y todo ello a través de un procedimiento flexible, abierto, dirigido por mediadores capacitados para gestionar estas habilidades, que facilitan la comunicación y las respuestas que se pueden dar desde y con las personas directamente afectadas, víctimas y victimarios.

Todos estos ingredientes han favorecido la incorporación de la mediación penal. Se presenta como un componente más de la justicia penal neomoderna; un instrumento con más bondades que desventajas, con todo y que no debe ser el cauce ordinario de presentación social de la justicia penal, empero, sí un buen procedimiento que trabaja para conseguir mayor paz social, más reconocimiento y por tanto más respeto hacia el otro, más incorporación de valores que permiten confiar en el ser humano, amén de ofrecerse políticamente como un magnífico medio para reducir el imparable y exponencial aumento de las causas penales en la realidad judicial actual; en suma, se visibiliza como un método eficiente de la justicia. 


\section{CONTEXTO EN EL QUE SE INTEGRA LA MEDIACIÓN PENAL: QUIEBRE DEL PARADIGMA DE JUSTICIA PENAL Y REPROGRAMACIÓN DE LA JUSTICIA NEOMODERNA}

La mediación penal y su incorporación en los ordenamientos jurídicos no ha sido fruto de un cambio legislativo, ni siquiera de un momento concreto o por unas circunstancias concretas. Se puede decir, sin temor a equivocarnos, que los obstáculos que inicialmente encontró la implementación de los programas de mediación penal se encontraban en el modelo de justicia penal, un modelo en el que las víctimas carecían de cualquier protagonismo, en el que el Estado asumía el ejercicio del ius puniendi a través de un único medio, el proceso penal, y en el que los pactos o acuerdos no tenían, salvo muy excepcionales situaciones, viabilidad alguna en dicho sistema.

La configuración del modelo penal, que nos ha ido acompañando, se asentaba en una evolución histórica de la sociedad, de la concepción política y religiosa y de las diversas corrientes que fueron influyendo y exigiendo un sistema justo y garantista, que abandonara las ordalías como medios probatorios, en las que el juego de la brujería y la divinidad generaba respuestas de la comunidad o grupo ante la posible comisión de hechos reprochables como colectividad, y también que fuera progresivamente abandonando el sistema jurídico procesal penal, que encontró en el procedimiento de la Inquisición un modelo perfeccionado, técnico, que consagró las "maneras inquisitoriales" en la persecución de los hechos reprochables socialmente. Una persecución que se vino identificando más con la idea del mal, del pecado, que con la concepción moderna del control social. ${ }^{4}$

La historia mostró las dificultades iniciales, aun cuando exitosas progresivamente, para desprenderse de las "maneras procedimentales inquisitoriales". ${ }^{5}$ La estrecha vinculación del poder político con el poder religioso

4 La idea de "pecado" que la Iglesia atribuía a aquellos comportamientos nocivos para la comunidad fue trasladándose al ámbito jurídico, y evolucionando hasta la construcción del "delito" como afrenta contra lo público, contra la sociedad, y exigiendo procedimientos y reglas de actuación frente a ellos. Se fue construyendo el mundo del derecho desde dos bloques: el derecho privado, con infracciones y sanciones disponibles para las partes y el proceso civil, asentado en la oportunidad y la disponibilidad; y el derecho penal, con delitos que trascienden de la esfera individual y se proyectan sobre la sociedad en su conjunto, por conductas reprochables desde la comunidad, y para su castigo se requieren métodos más duros, controlados por el poder político y eclesial (Alessi, 2001: 13).

5 Sobre la historia del proceso penal véase Barona Vilar (2017a).

Esta obra está bajo una Licencia Creative Commons

Atribución-NoComercial-SinDerivar 4.0 Internacional, IIJ-UNAM.

Boletín Mexicano de Derecho Comparado, núm. 155, mayo-agosto de 2019, pp. 685-720. 
generó una enorme influencia en la sede penal, de la manera en que se perseguía y se castigaba por los pecados cometidos, con una asimilación de las técnicas y perfeccionamiento procedimental para aplicar los métodos de interrogatorio y de instrucción que la Inquisición diseñó y aplicó para el castigo de los herejes. Esa influencia vino favorecida por la aparición de los estudios jurídicos en las universidades europeas. Los juristas eran formados en las universidades y la formación se impartía por los canonistas, cultos, conocedores del latín, convertidos en profesores universitarios, y fueron quienes favorecieron, entre otras cosas, la aprobación de las Decretarles papales y la obra científica que permitió expandir la fe cristiana, y también los ritos que se fueron aplicando por la Inquisición romana, inicialmente configurada para la lucha contra las herejías, que inspiró las maneras procedimentales para responder ante los reproches sociales penales (Salvioli, 1969: 356-357; Barona, 2017a: 108-109).

Las doctrinas y corrientes de pensamiento que emergieron a lo largo de los siglos - humanistas, la Ilustración, el pensamiento revolucionario, etcétera - favorecieron la transformación de ese modelo inquisitorial penal, que se circunscribía al instrumento del tormento y la tortura como métodos de averiguación de la verdad, o lo que es lo mismo, como la vía adecuada para que quien quedaba afecto a un proceso como acusado - cosificado en todo caso - confesara los hechos. Lo que importaba bajo la inspiración de la Inquisición era conseguir la condena como fin esencial del procedimiento penal y, por tanto, el castigo del acusado. Fue progresivamente exigiéndose un cambio de modelo, una evolución transformativa que, virara hasta ubicar al acusado como eje del sistema garantista penal, o lo que es lo mismo, se produjo el efecto pendular de la cosificación a la conversión de persona con derechos o, en términos expuestos por Hannah Arendt en su obra El origen del totalitarismo, en "persona con derecho a tener derechos".

En esa evolución se produjo un paso adelante en la conformación del proceso penal, un verdadero instrumento a través del cual se desarrollaban dos fases: una primera, sumarial, inquisitiva y secreta, sin participación del sospechoso y que servía para preparar el juicio; y una segunda fase plenaria acusatoria, que servía para fijar las posiciones y para producir las pruebas de las partes. Algo iba cambiando por cuanto el proceso respondía a esas necesidades de garantizar a la sociedad la búsqueda de la verdad desde y por el respeto a los derechos del sujeto (ya no objeto ni cosa) del 
proceso penal. Todo ello sin perjuicio de considerar que, pese al diseño de estas dos fases, el peso de la fase sumarial era mayor que el plenario, lo que perturbaba, cuando no frustraba, el modelo legalmente consagrado.

El tiempo también lo curó todo, y así fue avanzado el siglo XX, cuando las reformas procesales penales y el auge del constitucionalismo moderno de ese siglo propició un cambio, tanto en la ley como en la cultura procesal penal. El proceso se convirtió en el instrumento en el que se determina si hubo hecho, si éste era delictivo, si existe culpable, y si debe o no aplicarse la consecuencia penal derivada de la comisión del hecho delictivo. De este modo, el proceso sirve tanto a quien siendo culpable se le debe imponer la consecuencia jurídica, con garantías, como a quien no siéndolo se le declarará inocente, todo a través de ese proceso con garantías.

Éste fue el paradigma de la justicia penal ${ }^{6}$ durante un periodo que vino marcado por las conquistas del ciudadano, por sus derechos, por la consagración constitucional de los mismos. Un paradigma que fue calando en la sociedad moderna de Occidente, en la que el sistema procesal penal viraba sobre el Estado, un Estado potente, que ejercía una misión protectora de sus ciudadanos - que fueron perdiendo la condición de súbditos-. Pero, ya no hablamos de un Estado totalitario, sino de uno especialmente protector, y ello por cuanto asume funciones impulsoras de la denominada justicia social del siglo XX (Barona, 2017a: 259-274). El Estado consideraba políticamente a la justicia como uno de los pilares esenciales del Estado. Desde esa concepción ideológica de la justicia al Estado, le importa no solo diseñar, sino también costear y controlar el ejercicio del derecho reconocido a los ciudadanos, a los medios y a los protagonistas del mismo.

En ese paradigma, difícilmente tenía, y podía no tener, buen encaje un instrumento como el de la mediación, precisamente por la ausencia de la víctima, por su invisibilidad, por su estado de "nada" o vacío legal, ${ }^{7}$ que

6 Kuhn (1962: 57) se refería al término "paradigma" referido, desde su posición de filósofo y científico, a lo que denominaba los "dogmas científicos", esto es, las "realizaciones científicas universalmente reconocidas que, durante cierto tiempo, proporcionan modelos de problemas y soluciones a una comunidad científica". Consideraba "paradigma" una estructura conceptual en la investigación científica que los científicos no ponen en duda. Ese concepto se puede cambiar a lo largo de la historia debido a crisis o rupturas traumáticas de los dogmas o criterios, generando lo que denominó la "crisis del paradigma".

7 En la doctrina inglesa se le denominaba originalmente legal nonentitiy, así lo refiere Fattah (1991: 45). Se tradujo al alemán este mismo término como rechtlichen Nichts, al que se refiere Kilchling (1995: 1). 
respondía a ese modelo de justicia penal en la que el Estado asumía la persecución de los hechos y la aplicación del reproche correspondiente. Los hechos delictivos son afrentas a la sociedad. Las víctimas fueron apartadas del proceso penal a medida que la línea entre el proceso penal y el civil era más nítida. Se produjo lo que algún autor consideró como la expropiación del conflicto a las personas que originariamente se hallaban involucradas en él (Highton et al., 1998: 41).

Hay que considerar que, en ese interés del Estado por "lo penal", el desequilibrio entre los dos ejes del sistema - el derecho penal y el derecho procesal penal - ha sido una constante. Si bien, hemos asistido a una profusión del derecho penal, a una maximización del mismo, a una expansión, a una concepción del derecho penal como un "sanalotodo", no se ha mostrado paralelamente interés con la misma intensidad por el proceso penal, máxime cuando éste es el medio a través del cual es posible aplicar el derecho penal al caso concreto. La evolución ha sido (por mucho) siempre más lenta en materia procesal penal que en materia penal. No en vano, Carnelutti (1946: 73) hablaba del proceso penal como la "cenerentola del derecho procesal".

En las últimas décadas del siglo XX, y en el XXI, hemos asistido a un imparable crecimiento y expansión del derecho penal. Bajo el contexto de la sociedad mundial del riesgo (Beck, 1999; véase también Beck, 2004: 421439), concepto que engloba "la sociedad mundial", la "sociedad de la información" y la "sociedad del riesgo" que tanto inciden sobre la evolución de la criminalidad (Sieber, 2008: 126-127; y previamente, Sieber, 2006: 35-79), los poderes públicos responden con mayor control social, ante una amenaza de inseguridad global. La respuesta penal pasa de ser la ultima ratio a la primera, y se insiste, de forma peligrosa, en una urgente necesidad de protección de la seguridad ciudadana - repárese, no seguridad de los ciudadanos, sino una suerte de mantenimiento del orden-, en detrimento de los derechos de la ciudadanía. La insatisfacción y el desencanto ante esto ha encontrado contestación en las aulas y también en la calle (Zaffaroni, 2006: 229).

La globalización ha influido de forma palmaria. Evidentemente esos nuevos riesgos de la sociedad moderna existen, y en gran medida las causas técnicas, o, si cabe, los desarrollos técnicos (Bonss, 1995: 80), así como los económicos y los políticos, derivados del movimiento global, han pro- 
pulsado mayor complejidad delictiva, favoreciendo la aparición del "derecho penal de la seguridad".

Todo esto presenta un quiebre del viejo paradigma de justicia penal (protectora y garantista), un quiebre que ha venido acompañado de una reprogramación del modelo de justicia, que presenta en muchos casos una clara involución y regresión en las conquistas de derechos, en las garantías procesales.

Las variables sociales, sociológicas, políticas, económicas y culturales presentan una sociedad más compleja que ha favorecido los altos índices de conflictividad y de diversidad conflictual, amén de un imparable aumento exponencial de la criminalidad, siendo muchos los causantes de esta situación: por un lado, la complejidad social ha favorecido las desigualdades, las angustias y los desencantos, ha fomentado las frustraciones y, en ciertos casos, las actitudes reaccionarias y violencias, cuya respuesta ha ido cada vez más encontrando respuesta penal; por otro, la realidad social inquietante que se nos presenta favorece, requiere y exige cada vez más derecho penal. Aquel pasado en el que el derecho penal era considerado como la ultima ratio ha desaparecido y tenemos un derecho penal omnipresente, que alcanza a todos los ámbitos de las relaciones jurídicas y se convierte en la primera opción para la ciudadanía. Se presenta como la mejor y más rápida de las posibles respuestas que los poderes políticos pueden ofrecerle. Ahora bien, ni la sensación y percepción de frustración y desencanto de la ciudadanía ha disminuido, ni tampoco lo ha hecho en estos últimos tiempos la criminalidad.

En ese escenario se produce paulatina, pero imparablemente, un cambio de paradigma de la justicia penal, abandonando los postulados liberales y los del Estado social de derecho, para propiciar una transformación de dicha justicia, una transformación que se justifica en la new society (global, económica, digital, tecnológica, pragmática, y también líquida) ${ }^{8}$ que nos ha tocado vivir y en la que los parámetros o estándares de justicia también se han reprogramado. Se busca el control y la seguridad, una evidente expansión del derecho penal, ${ }^{9}$ una fascinación por éste que ha llevado a

8 Posición que hemos mantenido en el desarrollo de aquellos componentes que nos hacen aplicable la noción de Bauman de la liquidez a la justicia penal, considerando al respecto que estamos ante un escenario de justicia penal líquida (Barona, 2017b).

9 Hablar de la expansión del derecho penal exige conocer la obra de Jesús María Silva Sánchez, y muy especialmente la que publicó en 2011, a través de la cual exponía los fundamentos de esta construcción.

Esta obra está bajo una Licencia Creative Commons

Atribución-NoComercial-SinDerivar 4.0 Internacional, IIJ-UNAM.

Boletin Mexicano de Derecho Comparado, núm. 155, mayo-agosto de 2019, pp. 685-720. 
aprobar, bajo una denominada ola de emergencia, normas que suponen una verdadera inflación y endurecimiento de la ley penal (Barona, 2016: 49-50), provocando lo que se ha denominado como el neopunitivismo o la cuarta velocidad del derecho penal. ${ }^{10}$

Asistimos a un derecho penal cada vez más rollizo, empero, sin que venga acompañado de un interés por el proceso penal, que, a la postre, es el instrumento que se ha diseñado en las sociedades modernas y neomodernas para garantizar derechos y libertades, tanto personales como sociales. Se diseñan sistemas procesales penales acusatorios que quedan, en muchos casos, en papel mojado, por causa de esa exigencia de reprogramación del derecho penal de la seguridad. Se requiere respuestas rápidas, inmediatas si cabe, a esa criminalidad que se le escapa cada vez más a los Estados, que supera sus fronteras, que favorece el discurso de la securitization, que incorpora nuevos actores en la persecución y respuesta a la criminalidad: aparecen comisiones intrarregionales de cooperación y auxilio, nuevos tribunales supranacionales o internacionales, que favorecen una respuesta globalizada, que lamina en muchos casos lo "local", lo propio, que queda catapultado por una primacía del pensamiento global (Barona, 2018); obviamente un pensamiento diseñado por los más poderosos. En suma, se justifica una necesidad de mayor control social, dirigiendo una sociedad enceguecida que quiere justificar - empleando términos de Habermas - "la expansión e intensificación de sus propias fuerzas con la expansión e intensificación de las fuerzas del otro"; es decir, un "más derecho penal" o "una expansión masiva de lo penal" (Habermas, 1991: 432), cercenando los axiomas democráticos, los derechos fundamentales y los derechos humanos. ${ }^{11}$

En esta sociedad altamente esquizofrénica que proyecta riesgo, miedo, y control, bajo un modelo penal de la seguridad, se alimenta un modelo de tutela penal de dos velocidades: el sistema represivo, restrictivo y negativo de derechos y garantías para "los otros", los enemigos del sistema y de la sociedad (los débiles, los de otras religiones, los de otra raza, los de otros países, etcétera); una suerte de incorporación de bondades que permiten la abreviación de los procedimientos, los acuerdos, los pactos, las reducciones

10 Para un desarrollo de esta profusión de neopunitivismo, véase Pastor (2005).

11 Planteamiento que realizamos en los primeros años del siglo XXI referidos precisamente a estos postulados que la globalización incorporó a la sociedad (Barona, 2004). 
de penas o las sustituciones de éstas, por otras consecuencias jurídicas diversas, pensado todo ello para "nosotros".

Es en el marco de esa esquizofrenia jurídico-penal y procesal penal cuando la reprogramación del modelo y del sistema va a ir integrando e incorporando unos mecanismos que se denominan "alternativos", "salidas", "premios", "acuerdos", que van a ir favoreciendo la incorporación de la justicia penal restaurativa. Y esa justicia penal restaurativa va a necesitar de unos servicios restaurativos, regulados en los ordenamientos jurídicos, para la protección de las víctimas y para favorecer políticas resocializadoras. Con todo ello, se produce el "resurgimiento" de las víctimas, ${ }^{12}$ y con ellas, la incorporación de criterios de oportunidad en los procesos penales acusatorios.

Ahora bien, este retrato también va a propiciar una aplicación de varias velocidades del sistema penal y procesal penal, con línea divisoria entre poderosos y débiles, entre ricos y pobres. Esa separación entre nosotros y ellos, entre amigos y enemigos, supone una crisis profunda de la igualdad. Ha sido contestada, entre otros, por Ferrajoli (2016: 19), quien denuncia la crisis rotunda del derecho penal y su ineficiencia para dar respuesta a estas nuevas formas de criminalidad y la necesidad de una imprescindible mutación del derecho penal, que permita hacer frente a este nuevo escenario, que lucha contra lo que Maier denominó como un derecho penal "sanalotodo" (Maier, 2009: 117).

En ese escenario, y favorecido por el modelo procesal penal acusatorio y el principio de oportunidad, emerge una institución, la mediación penal, que permite trabajar presuntas víctimas y presuntos victimarios para alcanzar respuestas restaurativas también incorporadas al proceso penal y con efectos procesales; por ejemplo, el acortamiento del proceso para dar contenido a la resolución que pone fin al mismo, con todo y que la mediación permite alcanzar "acuerdos reparatorios" que, irradian beneficios a las víctimas, a los victimarios y también a la sociedad misma; acuerdos que no son sino la especie del concepto genérico que se consagró con la justicia restaurativa. Ésta integra esa suerte de acuerdos reparadores o reparatorios, expresión de la función de restaurar genéricamente considerada. La reparación moral o material a las víctimas, a los victimarios y a la sociedad, permiten la culminación del modelo restaurativo.

12 Estudio detallado sobre la víctima, véase en Gómez Colomer (2015).

Esta obra está bajo una Licencia Creative Commons

Atribución-NoComercial-SinDerivar 4.0 Internacional, IIJ-UNAM.

Boletín Mexicano de Derecho Comparado, núm. 155, mayo-agosto de 2019, pp. 685-720. 


\section{MODELO RESTAURATIVO, UNA BOGANADA DE AIRE FRESCO ANTE TANTA EXPANSIÓN NEOPUNITIVISTA}

Hemos asistido a una paulatina incorporación de la justicia restaurativa en estas últimas décadas, y con ella, o tras ella, la mediación penal se ha colado en los ordenamientos jurídicos. La mediación penal no es la única manifestación de la justicia restaurativa, pero sí es probablemente la que mayor entidad ha adquirido en los sistemas jurídicos, presentándose como un procedimiento complementario del proceso penal, en el que bajo la dirección de un mediador o un equipo técnico de mediación, con intervención de víctimas y victimarios, y con aplicación de técnicas de escucha activa, comunicación, diálogo, etcétera, se puede dar debido cumplimiento a las tres funciones del derecho penal: la preventiva, la resocializadora y la restaurativa.

En unos casos, el espacio ganado por la mediación ha sido por convicción, en respuesta a esa necesidad de dar visibilidad a las víctimas, de garantizar la resocialización del autor de los hechos y de favorecer una reducción de la criminalidad; si bien en otros casos se ha presentado como medida "eficiente", a saber, como un anillo más de la larga cadena de instrumentos que pretenden alcanzar ese "menos proceso". ${ }^{13}$

El modelo restaurativo penal ha adquirido un verdadero protagonismo a finales del siglo XX y ya está consolidado en el XXI. No ha surgido para sustituir los fines preventivos de la pena, sino para formar parte de un todo, de manera que convivan componentes retributivos, preventivos, resocializadores y restaurativos (Sherman y Strang, 2007: 52). Así, la justicia restaurativa ha ido adentrándose en la mayor parte de los países y sistemas jurídicos, se ha colado entre sus funciones, afianzándose en numerosas manifestaciones que hoy son ya incuestionables (Barona, 2011: 27-40).

En una sociedad con una enorme crisis de identidad, estructural y coyuntural, y con una absoluta regresión de las garantías, la justicia restaurativa insufla nuevos planteamientos sociales, integradores colectivamente y de convivencia, que inspiran una verdadera y mejor transformación so-

13 Si el empleo de la mediación penal se realiza desde las gafas del pensamiento economicista, una institución como ésta podría ser presentada con optimismo político, al considerar que favorece el acortamiento de los procesos y con ello menos trabajo, menos desgaste de medios, de personal y mucho menos presupuesto económico; es decir, estaríamos simplificando las cosas para licuar mucho más el proceso, propiciando su liquidez (Barona, 2017a: 614). 
cial, tan necesarios en estos momentos. ${ }^{14}$ Con la introducción de conceptos como "reconocimiento del otro", "escucha", "paz", "diálogo", "responsabilidad", etcétera, se ofrece una bocanada de aire a una sociedad descreída, con la economía como elemento inspirador, con falta de asideros, vacua, desmotivada y desilusionada (Barona, 2015: 202-203).

El espíritu restaurativo se presenta como una bocanada de aire que ha venido en gran medida impulsada y favorecida, con mayor o menor intensidad, por teorías o movimientos, tales como las teorías abolicionistas, ${ }^{15}$ los movimientos feministas, los movimientos humanistas, la victimología, así como los movimientos restorative justice y de justicia reconstructiva. Este modelo se asienta en la combinación de la trilogía víctima-infractor-sociedad (o Estado, en suma) para poder alcanzar el equilibrio. Ofrece una respuesta desde las personas, trabajando el reconocimiento del otro, que, obviamente pasa por otorgar la posibilidad al delincuente de responder ante las víctimas, responsabilizándose de la reparación del daño causado. También las víctimas tienen la posibilidad de reconocer al otro, escuchando su relato.

Son plurales las denominaciones que se han incorporado. Podríamos considerar que estos componentes expuestos darían lugar a lo que se denomina "justicia restaurativa", como género conceptual. Y con ella se ofrece una mirada de la justicia diversa. Esa mirada, sin embargo, puede centrarse en la reparación, y por eso se habla de justicia reparadora (entendiendo reparación tanto la moral como la económica, empero también la simbólica), y también se ha extendido a lo que, especialmente en ciertos ámbitos (políticos y complejos) se ha denominado "justicia reconstructiva"; en esta última, existe un objetivo esencial: alcanzar la paz social, una paz que en

14 Se asume un punto de vista subjetivo diverso cuando ya no pivota el modelo exclusivamente sobre el delincuente y la respuesta social frente a las conductas antisociales, aceptándose que las víctimas tienen un protagonismo en el mismo. Asistimos, por ello, al momento en el que se pretende desentrañar el sentido profundo del dogma de la neutralización de la víctima, en palabras de Tamarit Sumalla (2005: 31), que se encuentra en la superación de la autotutela, la sublimación y racionalización de los instintos de venganza, la minimización de la violencia, la democratización de la seguridad y la voluntad de impedir la negación de la dimensión humana del infractor y, por lo tanto, los derechos del mismo y el due process, el derecho a un proceso justo, amén de la opción por la reinserción social.

15 El planteamiento y los desafíos de los abolicionistas, o si cabe en algunos casos minimalistas, puede verse en la obra de Christie et al. (1989), en la que se sostiene la ineficiencia y frustración del sistema punitivo y por ello se defiende su abolición y, en todo caso, su reducción a mínimos. 
ocasiones exige comisiones de la verdad, exige "orillear las normas penales", exige indultos, todo ello bajo una necesidad de recomponer una sociedad dividida o destruida, especialmente por el odio, el rencor, la violencia sufrida, etcétera; una sociedad en la que el sistema penal legalmente establecido no solo no alcanza a dar respuesta satisfactoria, sino que la respuesta es la menos adecuada para alcanzar la reconstrucción social. En el caso de la justicia restaurativa las funciones del sistema penal siguen presentes; por ejemplo, en el caso de la justicia reconstructiva, ${ }^{16}$ existen fines superiores a la norma penal que justifican su misma inaplicación. Sin embargo, en ambas manifestaciones, el diálogo y la comunicación son los elementos nucleares que componen esa mirada de la justicia.

Hay quien ha defendido que el modelo restaurativo comporta un nuevo estilo de vida, dado que no sólo se concibe como una aportación hacia la reforma del sistema de justicia criminal, sino que "es un camino para transformar el sistema legal en su conjunto, nuestro estilo de vida, nuestra conducta en el ámbito laboral y la manera de actuar de los políticos" (Braithwaite, 2003: 1), un proyecto intelectual y político mucho más ambicioso de lo que normalmente se ha venido considerando (Braithwaite, 2003: 18). Esta idea parte en su concepción de la necesidad de actuar frente a lo que denomina como "injusticia preventiva".

La experiencia de modelos restaurativos de algunos sistemas anglosajones sirvió para manejar las prácticas de diálogo y reconciliación entre víctima y ofensor. Su estrecha vinculación con el movimiento de la solución alternativa de conflictos fue evidente, especialmente con el movimiento de recuperación de las víctimas, en cuanto se integraba perfectamente en la filosofia de la huida de lo estatalmente establecido, de los parámetros para-

16 Este concepto de "justicia reconstructiva", ha sido tratado en la obra de Reyes Mate (2011: 208 y 236-239), quien considera que, frente a las injusticias que destruyen la sociedad, "la justicia debe reconstruir", refiriéndose especialmente a situaciones que se han venido soportando en países como Irlanda, Colombia, España o Italia, por motivos de terrorismo, entendiendo que tras un periodo insoportable de destrucción y de tiranía del odio es necesaria la reconstrucción, siendo a estos efectos la mediación un buen procedimiento para permitir a la sociedad y al Estado mantener el control en el marco de los intereses generales, un medio para "suturar" la fractura provocada en la sociedad por la duradera y continua destrucción social por acciones terroristas. Este autor considera que "la justicia es como un ánfora rota cuya reconstrucción depende de que encontremos a cada parte su trozo correspondiente. Las partes no son iguales, como no lo son los trozos de un objeto roto... La justicia reside en el reconocimiento de cada trozo como un fragmento del todo o, dicho de otras maneras, en la respuesta a la injusticia". 
digmáticos de actuación en materia penal y ese movimiento hacia la búsqueda de la paz social.

No se trata de sustituir una función por otra (Barnett, 1977: 279), a saber, la retributiva y preventiva por la reparativa o restitutoria, sino integrarlas (Sherman y Strang, 2007: 52) en cuanto ambas son especies de la justicia distributiva, pretendiéndose en la restauración de la distribución de los derechos existentes antes de que se produzcan los hechos, en la medida de las posibilidades, sin olvidar que también a través de la justicia restaurativa se imponen consecuencias jurídico-penales al autor - devolución de lo robado, expresión de arrepentimiento, compensación a las víctimas-, pero, en todo caso, una consecuencia que tiene un claro efecto retributivo. ${ }^{17}$

Y por supuesto no se trata de sustituir un delito como ofensa social por conflicto individual, ni eliminar la defensa del interés social por el de la víctima, sino la intrínseca simbiosis de ambos, lo que abre las puertas a un nuevo paradigma de justicia, tal como lo entendió Zehr, uno de los padres de la restorative justice. ${ }^{18}$ Ante la inoperancia del sistema penal, este autor propone un modelo de justicia basado en la concepción del delito como una violación de las relaciones humanas, de manera que los sentimientos de las víctimas y del ofensor no se deben ver como algo periférico, sino como, el elemento nuclear del problema. El sistema se debe focalizar no tanto en el pasado como en el futuro, siendo la restoration el elemento de este nuevo paradigma de justicia, es decir, tratar de recomponer las relaciones sociales en lugar de imponer sufrimiento.

En el paisaje penal involucionado, regresivo, también entrópico y contradictorio viene adquiriendo espacio la mediación penal, una bocanada de aire (Barona, 2017a: 606) que permite una mirada desde las personas. Llegó bajo la fórmula de proyectos piloto en responsabilidad penal de menores, actuando como banco de pruebas suficiente para su incorporación posterior. Su imbricación en el sistema penal sancionador, a través de la

17 Según Duff (2004: 54), la pena debe tender a comportar im primis una forma de diálogo con el autor del hecho, reconociendo su responsabilidad que se activa con el mantenimiento de un face to face con la víctima. Puede verse igualmente su posición más in extensum en Duff (2001).

18 Zehr sostenía que no había que enfrentar la justicia restaurativa con la retributiva; lo hizo en 1990 con la aparición de su primera obra, y lo reiteró doce años después (2002: 58-59) cuando defendía: "Despite my earlier writing, I no longer see restoration as the polar opposite of retribution".

Esta obra está bajo una Licencia Creative Commons

Atribución-NoComercial-SinDerivar 4.0 Internacional, IIJ-UNAM.

Boletín Mexicano de Derecho Comparado, núm. 155, mayo-agosto de 2019, pp. 685-720. 
valorización de la reparación ha supuesto una relectura de aquél desde los derechos humanos (Mannozzi, 2012: 845).

\section{ELEMENTOS QUE COMPONEN LA ARQUITECTURA \\ DE LA MEDIACIÓN PENAL}

La misión restaurativa debe desarrollarse a través de un cauce que la haga exequible. El proceso penal servirá para arropar las consecuencias derivadas de una mediación penal que finalice con acuerdos reparatorios, empero no está diseñado para que el juez que lo dirige asuma la función autocompositiva que es la propia de un mediador, amén de la heterocompositiva, que es la propia de un juez que ejerce función jurisdiccional.

Es por ello que la mediación penal es el instrumento a través del cual se va a poder ejercer la función restaurativa. Es un escenario adecuado para acoger y garantizar el desarrollo de encuentros o prácticas restaurativas que ofrecen una nueva visión de la justicia penal, asumiendo que la justicia está al servicio de los ciudadanos y no al revés, trabajando con herramientas en las que adquiere protagonismo el ser humano y no el sistema, con todo y que sus resultados, a la postre, revierten positivamente en el mismo. Esa manera de actuar es también una forma de "hacer justicia", una forma que se ha colado en los ordenamientos jurídicos, con argumentos penales, procesales y de política criminal que la han favorecido en este momento histórico, caracterizado por la evolución y adaptabilidad a la realidad.

Implica el conocimiento de un método de trabajo, muchas dosis de energía y voluntad de que alcance resultados positivos y un buen abrigo legal para integrar la mediación penal en el proceso penal o, si cabe, afirmar que no es que estemos ante una vía alternativa a la vía jurisdiccional, sino ante una vía complementaria a la misma. Ciertamente esa estrecha vinculación de la mediación con las soluciones alternativas de conflictos, en cuanto modalidad de las mismas, ${ }^{19} \mathrm{es}$, en gran medida, lo que ha propiciado que en algunas legislaciones se quisiera verla como un "sistema

19 La solución extrajurisdiccional de conflictos (alternativa o complementaria) vino a generar un movimiento en el mundo anglosajón, que quedó representado bajo las siglas $\mathrm{ADR}$, esto es, supuso en sus orígenes alternative dispute resolution, si bien el paso del tiempo dejó de ser necesariamente alternativo para ser método complementario del proceso judicial. Se ha seguido manteniendo las siglas en el mundo anglosajón de ADR (o también RAC o MASC en el mundo latino), para otorgar significado a lo que se denomina como 
sustitutivo del proceso penal". Insistimos, pese a todo, no es alternativo ni sustitutivo, sino complementario. Si fuera alternativo sería excluyente del proceso, y no lo es. Es componente integrador y a integrar en el proceso penal. Solo así puede quedar cubierto por las garantías exigibles en un sistema de justicia integrado en un Estado democrático de derecho.

Forma por ello parte de esa nueva visión de la justicia integral, que ofrece multidoors de acceso a la tutela efectiva; tutela que comúnmente ha tenido una única vía - proceso - y unos únicos actores - los jueces - y cuya presencia es palmaria también en materia penal. La incorporación de estos nuevos instrumentos ha ido conformando, en el marco de la tutela, un nuevo paradigma de justicia, abandonando el modelo monolítico judicial y procesal, para dar paso a la mediación y a nuevos protagonistas, como los mediadores.

La mediación penal es uno de los cauces de tutela que se presentan al ciudadano, ofreciéndole una vía complementaria, más accesible y con efectos favorables, tanto para la víctima como para el victimario, desde el reconocimiento mutuo - y también por el Estado - de su capacidad para consensuar. Esta vía no pretende sustituir al proceso penal ni a los autores de la persecución penal, sino trabajar con ellos y favorecer una respuesta que cuanto menos satisfaga tripartitamente a quienes se ven inmersos en la causa penal: la sociedad, las víctimas y los ofensores. Así las cosas, hay que naturalizar a la mediación penal para configurar los elementos que componen la misma, lo que significa arrancar de la consideración de la mediación como medio de tutela penal, cauce para la aplicación de la reinserción, la reparación y el reestablecimiento de la paz social, elementos propios de la justicia restaurativa (Barona, 2011). Los elementos que integran este cauce son, por ende:

1) Es una modalidad de tutela del ciudadano, junto a la tutela judicial, que en muchos casos trabaja para gestionar, desde el diálogo, la reconstrucción de la paz social, quebrada por el hecho delictivo, lo que permite la minimización de la violencia estatal, devolviendo, en consecuencia, cierto protagonismo a la sociedad civil (González, 2009: 25). Esta vía complementaria cumple igualmente los tres fines del sistema penal (preventivo, resocializador y restaurativo).

adequated dispute resolution. Puede verse un desarrollo del nacimiento y evolución de este movimiento y su incorporación en diversos países (Barona, 1999).

Esta obra está bajo una Licencia Creative Commons

Atribución-NoComercial-SinDerivar 4.0 Internacional, IIJ-UNAM.

Boletín Mexicano de Derecho Comparado, núm. 155, mayo-agosto de 2019, pp. 685-720. 
2) La mediación se fundamenta en la libertad o voluntad de las partes de sometimiento a la misma. Esto significa que quienes acuden a la mediación penal, víctima e infractor, lo hacen como un verdadero acto de libertad, sin coerción. La cuestión es determinar si se acude por voluntad bilateral de las partes o sí es posible acudir por remisión del juez o del fiscal. Existe en algunos ordenamientos jurídicos la atribución exclusiva, en cuanto a la incoación del procedimiento de mediación, al fiscal (como sucede, a título de ejemplo, con el modelo francés). ${ }^{20}$ Parece más coherente con los principios esenciales del ius puniendi que deba ser de oficio la decisión final de remitir o no al procedimiento de mediación, sin perjuicio de que la iniciativa pueda partir de las partes.

Un modelo interesante es el alemán (Täter-Opfer-Ausgleich), que establece que tanto el fiscal como el juez (éste solo hasta la formulación de acusación, en fase pretrial, artículo 153a.1, 1o. y 5o. de la StPO, y artículo 45.2 y 3o. del Código Penal de menores), puedan derivar a mediación, permitiéndose incluso en juicio oral, suspendiéndose éste mientras dure la misma (artículo 155a de la StPO). Así, la regulación en Alemania viene a consagrar la máxima de que la reparación permite eliminar el interés público en la persecución del hecho y en la ulterior previsible condena penal. En el ordenamiento alemán se ha planteado también la posibilidad de que fuere la policía la que seleccionase los asuntos a llevar a mediación, aun con algunos detractores. ¿Y si se lleva a cabo de forma no oficial, entre las partes? Sin negar viabilidad a la misma, el interrogante se centra en el valor que pueda darse al acuerdo adoptado en mediacion, ${ }^{21}$ quedando la eficacia jurídico-procesal de ese acuerdo condicionada a la aceptación por decisión del fiscal y del juez, que valorarán si deciden continuar con el proceso o, por el contrario, proceder a archivarlo (Bannenberg, 1993: 23-24).

3) La mediación es un procedimiento, no es proceso. Aun cuando proceso y procedimiento tienen una misma raíz etimológica, procedere, el procedimiento existe en cualquier actividad jurídica, siendo la

20 Sobre el modelo francés, véase Etxeberría Guridi (2009: 200-201).

21 Esta denominación es la que se le da en Alemania a estas posibles mediaciones penales, que se desarrollan acudiendo a un servicio de mediación penal por decisión bilateral de la víctima y el autor de los hechos, y no por remisión del órgano público de persecución. 
manera formal en que se desarrolla aquélla, y proceso se refiere tan solo al ejercicio de la función de juzgar y hacer ejecutar lo juzgado de manera irrevocable, que no es sino la función jurisdiccional (artículo 117.3 CE). En el caso de la mediación no estamos ante función jurisdiccional, no actúa el mediador heterocompositivamente o supra partes, sino autocompositivamente o intra partes. No impone la decisión el mediador, sino que trabaja con las partes, aproximándolas, ayudándolas a asentar sus posiciones y sus intereses, que no son siempre los mismos. Este procedimiento no finaliza mediante una resolución, sino mediante un acta en la que se hará constar si se alcanzó el acuerdo entre las partes o no. Será la posterior incorporación a la resolución del acuerdo adoptado entre las partes lo que producirá efectos de cosa juzgada.

Debe ser un procedimiento flexible, poco formal, lo que no es óbice a la configuración de reglas en el procedimiento que comporten garantías (como el establecimiento de plazos) y que abrigue respeto a los derechos esenciales de igualdad, contradicción, derecho de defensa o presunción de inocencia, de modo que la informalidad, la flexibilidad y la no rigidez no comportan sino una manera de actuar que favorece la aplicación de los principios esenciales de intervención de las partes en cualquier forma de tutela efectiva de los ciudadanos (Trankle, 2007: 43).

4) Es un perfecto complemento del proceso penal, de ahí la necesidad de su integración en el modelo de justicia penal. Si bien la eficacia de un procedimiento de mediación penal puede llegar a alterar el desarrollo de un proceso penal, puede minimizarlo o puede suspenderlo, e incluso transformar el contenido de la condena penal en el proceso, no por ello puede afirmarse que estemos ante un cauce alternativo, sino, al contrario, ante un instrumento complementario de los tribunales.

5) La mediación se asienta sobre la intervención tripartita de sujetos, hallándose el mediador inter partes, esto es, entre la presunta víctima o persona que ha sufrido las consecuencias del delito y el víctimario, que es la persona presunta autora de los hechos delictivos. El mediador trata de aproximar a la víctima y al víctimario. El éxito de la mediación pasa necesariamente por dar la oportunidad a los sujetos de ser oídos. En esa función el mediador debe ser neutral e impar- 
cial, sin inclinarse a favor de una parte sobre la otra (Di Chiara, 2004: 501). Ello no implica ser mero espectador, sino mantener un papel activo, reuniendo a las partes, suavizando los ánimos encrespados, actuando como guía imparcial de la discusión y asegurando que todos tengan las mismas oportunidades de hablar. Y todo ello desde el debido respeto a la confidencialidad y con la visión constructiva de traducir el lenguaje negativo en uno positivo.

Es posible igualmente que intervengan en el procedimiento de mediación terceras personas (letrados - muy conveniente-, asesores, etcétera), colaborando con cualesquiera de ellas, no siendo ni la víctima ni el víctimario, sin que ello perturbe la idea de la bilateralidad. Hay que evitar la asimetría que se puede generar como consecuencia de esta posible participación de terceros, por lo que habrá de mantenerse la debida cautela.

6) Asentada en el principio de confidencialidad, esencia de la mediación, de manera que no debe transmitirse al juez los diálogos, debates, afirmaciones o alegaciones que se hayan realizado por las partes, sino tan solo conocerá del documento final, que es una especie de acta en la que se suscriben los posibles acuerdos, o no, de las partes. El mediador hará firmar un acta o documento de confidencialidad a las mismas. Esto comporta que si se volviere al proceso penal no debe tener valor incriminatorio lo volcado en confidencialidad por las partes en mediación, a salvo de que ambas estuvieren de acuerdo en otorgarle el valor probatorio a ciertas afirmaciones, expresiones o manifestaciones vertidas oral o por escrito por ellas. Lo contrario supondría un claro atentado al derecho a la presunción de inocencia, y provocaría - obviamente - un gran recelo a participar en la mediación por el presunto infractor.

7) Una de las cuestiones que se suscita en sede de mediación penal es si la derivación a la misma debe ser sufragada por las partes. Dada la naturaleza, significado y posibles consecuencias procesales penales, debiera ser gratuita para las partes. Cuestión diversa es la posible perversión que puede arrastrar la mediación penal gratuita, que no es otra que conseguir demorar el desarrollo del proceso penal con actitudes torticeras. El legislador podrá, en su caso, determinar salvedades, derivadas de conductas fraudulentas, que comporten una carga económica y excepcionen el principio de gratuidad. 


\section{V. ¿LÍMITES OBJETIVOS Y SUBJETIVOS PARA LA MEDIACIÓN PENAL?}

Uno de los ejes nucleares de polémica en torno a la mediación penal ha sido y es la configuración de los límites objetivos y subjetivos en el desarrollo de la mediación penal. Abre el debate a sí es posible acudir a mediación cualesquiera que fueran los hechos delictivos presuntamente cometidos, cualesquiera que fueran las consecuencias jurídicas que se pudieren aplicar y cualesquiera que fueren las presuntas víctimas y presuntos victimarios que puedan participar, o si, por el contrario, deberíamos considerar necesario establecer los límites objetivos y subjetivos a la misma. ${ }^{22}$ La cuestión es, por ello, si se defiende un modelo numerus clausus, limitantes y exclusivos, ${ }^{23}$ o si es exequible un modelo numerus apertus. ${ }^{24}$

La adopción de la primera opción obligaría al legislador a configurar el elenco de delitos-hechos delictivos que podrían plantearse en mediación penal, amén de unos criterios que fijen de forma clara y excluyente quiénes podrían, y quiénes no, intervenir como víctimas o victimarios en la mediación. Se trataría de una opción cerrada. Esta fue la opción asumida por algunos países que reconocieron legalmente la mediación penal, pero con cautelas, por cuanto frente a siglos de cultura judicial y procesal la mediación, como elemento extraño al sistema, no podía efectuarse de forma abierta e ilimitada. Así se vio, a título de ejemplo, en Alemania ${ }^{25}$ o en

22 La doctrina que ha marcado el análisis de la mediación penal en los diversos sistemas jurídicos ha debatido esta cuestión. Son numerosas las opiniones vertidas, que van desde una posición restrictiva hasta una posición permisiva con límites, hasta una necesidad de no restringir a ningún supuesto objetivo, y dejar a los directores de la persecución penal la iniciativa. Obra de interés a estos efectos es la de Bannenberg y Rössner (2003: 51-79), que incorpora las diversas posiciones, especialmente en la doctrina alemana.

23 En España, una posición limitativa la mantuvo Manzanares (2007: 53-55); y con ciertos condicionantes, entre otros, González Cano (2009: 40-43), refiriéndose especialmente al criterio de la gravedad.

24 Una posición muy amplia objetivamente hablando para la mediación es la mantenida por Ríos Martín (2006: 48), quien considera posible la mediación en todo tipo de delitos salvo cuando se produzcan atentados a la autoridad o delitos cometidos por funcionarios públicos en el ejercicio de su cargo, sin perjuicio de otros casos (delitos contra la libertad sexual, en materia de violencia de género, delitos contra la salud pública) sea el equipo técnico mediador el que valorará la conveniencia o no de la mediación, sin que esta prohibición venga determinada por la ley.

25 Las experiencias restrictivas de algunos estados federales en Alemania, determinados a priori en los protocolos que incorporaron los proyectos piloto en mediación con adultos

Esta obra está bajo una Licencia Creative Commons

Atribución-NoComercial-SinDerivar 4.0 Internacional, IIJ-UNAM.

Boletín Mexicano de Derecho Comparado, núm. 155, mayo-agosto de 2019, pp. 685-720. 
Francia ${ }^{26}$ en sus primeras regulaciones sobre mediación penal, en cuanto se fijaba de forma cerrada lo que se entendía podía ser a priori mediable o, lo que es lo mismo, establecieron límites objetivos a la mediación (sólo en caso de delitos bagatelarios, en los que no se haya empleado violencia sobre las víctimas, ni física ni psíquica; delitos económicos, delitos contra el honor, como calumnias e injurias; etcétera).

La realidad superó, empero, esta delimitación legal, favoreciendo al respecto un modelo de mediación penal que vendría no tanto determinado por las condiciones y supuestos legalmente establecidos de forma cerrada, cuanto por derivación de quienes en cada fase del proceso pudieren ser quienes ejercieren la persecución penal; esto es, se asumió como la fórmula más adecuada la de eliminar los límites legalmente establecidos y dejar que fuere el perseguidor penal el que remitiera en su caso a mediación, en atención a los hechos, pero también a las circunstancias concretas que pudieren concurrir para derivar a mediación penal.

La adopción de la segunda opción supone que no se defiende el elenco cerrado de supuestos que permiten acudir a mediación penal. Ahora bien, en este caso no se trata de habilitar la mediación penal en cualquier caso y para cada situación, sino que habrá que diseñar unos criterios que la hagan viable, amén de unas reglas de determinación de quién y cómo habrá que remitirse a la institución, una suerte de "protocolo". En esta opción se podría pensar en la necesidad de que en la ley se establecieran unos criterios que pudieran conjugarse a efectos de considerar adecuada la derivación a mediación.

Entre estos criterios se puede hacer referencia, en primer lugar y de forma generalizada, al de la "gravedad" (González, 2009: 40-41). Cuando los hechos sean considerados como graves no es recomendable que las víctimas lleguen a trabajar en mediación con los posibles autores (Man-

generaron una asimetría y una cierta frustración, que llevó a la desaparición cerrada de supuestos. Al respecto, Reuber y Rössner (2003) realizan en su trabajo un análisis de estas experiencias y de cómo incidieron como legislación complementaria (federal) en la regulación que finalmente pasó a incorporarse a la norma procesal penal alemana (Strafprozessordnung). También puede verse Kilchling (2008: 333). En la actualidad el artículo 46 del Código Penal alemán permite tanto delitos bagatelarios como graves, lo que no ha sido óbice a que algunos estados federales hayan querido ser más restrictivos.

26 Las experiencias dieron lugar a la necesidad de abrir esos límites en Francia (Mbanzoulou, 2004: 43, 44 y 53; Apap, 1990: 634), en los que se exponían las tensiones que las restricciones provocaron en el modelo francés. 
zanares, 2007: 53). Se asume el criterio objetivo puro, a saber, delitos que lleven aparejada una pena de gravedad. Este criterio no siempre es el más conveniente, dado que hay exponentes de delitos no graves que no es en absoluto recomendable mediar y, por otro, supuestos de hechos muy graves que, sin embargo, han sido planteados en una mediación, ${ }^{27}$ debido a que han sido las mismas víctimas las que han preferido trabajar en mediación para aprender a pasar duelo como consecuencia de la pérdida de un ser querido (fuere por un delito contra la vida o incluso por un atentado terrorista). En consecuencia, no necesariamente los delitos bagatelarios serían los más adecuados para mediación penal, excluyendo desde este criterio de gravedad los delitos más graves en atención al bien jurídico protegido y a la pena a imponer. ${ }^{28}$

Ciertamente, de los numerosos proyectos piloto que se suelen desarrollar en la mayor parte de los ordenamientos con carácter previo a la incorporación legal de la mediación penal, pueden significarse una serie de delitos que podrían en abstracto ser más proclives a la mediación penal (Barona, 2011: 298-301): delitos económicos, lesiones, amenazas o coacciones, injurias y calumnias, delitos contra los derechos y deberes familiares, especialmente por impago de pensiones, y asimismo delitos contra la salud pública. Insistimos, es un elenco ejemplificativo que puede favorecer respuestas en mediación, empero no por ello es excluyente, ni siquiera en todos los casos es inclusivo, porque las variables que pueden intervenir en cada caso pueden alterar las previsiones generales instaladas. Y se excluye de los mismos la violencia de género, siendo muy controvertida la viabilidad o exclusión de estos delitos por la enorme desigualdad emocional que suelen presentar las mujeres que acuden a una posible mediación con sus victimarios. ${ }^{29}$

27 En el mundo anglosajón se puede observar la opinión de Sherman y Strang (2007: 21) quienes consideran que en Gran Bretaña se trabaja mejor con mecanismos de justicia restaurativa cuando se trata de delitos con violencia, dada la función restitutiva, resocializadora y eficiente preventiva que se consigue.

28 A título de ejemplo, Ríos Martín (2006: 48) considera posible la mediación en todo tipo de delitos salvo cuando se produzcan atentados a la autoridad o delitos cometidos por funcionarios públicos en el ejercicio de su cargo), sin perjuicio de otros casos (delitos contra la libertad sexual, en materia de violencia de género, delitos contra la salud pública) sea el equipo técnico mediador el que valorará la conveniencia o no de mediación, sin que esta prohibición venga determinada por la ley.

29 En España la aprobación de la Ley Orgánica 1/2004, integral de medidas contra la violencia de género, en su artículo 44.5 excluía la mediación, lo que llevó a mantener una posición contraria a la mediación en estos casos, si bien existe en la actualidad una posi- 
A esta referencia de los límites objetivos debemos añadir la de los posibles límites o restricciones subjetivas. La cuestión es resolver si la mediación penal es apta para cualquier tipo de víctima o victimario o si, por el contrario, cabría establecer límites subjetivos a la misma.

En primer lugar, con relación a las víctimas, se cuestionaban los supuestos en los que las víctimas fueran plurales - que podría dificultar, pero no impedir en absoluto la mediación - (Barona, 2011: 310), ${ }^{30}$ o incluso que, no fueran determinadas, sino colectivas. En este último supuesto, en ciertos casos, los representantes de asociaciones o grupos podrían intervenir en el procedimiento de mediación. ${ }^{31}$ Igualmente se hablaba del rechazo absoluto de la intervención de víctimas de delitos sexuales, de violencia de género o violencia intrafamiliar que, si bien es cierto que, a priori pueden suponer una previsible conveniencia de no someterse a una victimización secundaria, puede igualmente ocurrir (como sucede en violencia de género pese a la prohibición legal en España, antes mencionada) la conveniencia de trabajar conjuntamente bajo el equipo de mediación para evitar la reiteración delictiva, para garantizar la autorresponsabilidad y para empoderar a la parte que acude a mediación inicialmente, y previsiblemente más débil (Ríos, 2006: 48). También se cuestiona la intervención en mediación penal de las víctimas especialmente vulnerables, como los menores o los incapacitados, ante las dificultades de alcanzar acuerdos que evidentemen-

ción diversa, pese a la norma, en gran medida motivada por las soluciones dadas en países como Alemania — donde se prohibió y posteriormente se consideró "posible" - o en Estados Unidos - donde se recomienda no acudir a mediación si existe en estos casos un palmario desequilibrio emocional entre víctima y victimario-, pero abriendo la puerta, tímida pero realmente, a la mediación penal, en aras de trabajar por eliminar sentimientos de odio, venganza, buscando soluciones que impliquen a ambas partes, y siempre que se trate de episodios esporádicos de violencia y no sucesivos y constantes. Interesantes son las aportaciones de Rakatomahanina et al. (2005: 4043) abogando por la viabilidad con base en los argumentos esgrimidos. En España, un estudio completo en torno a esta cuestión es la pequeña monografía de Patricia Esquinas Valverde (2008), que se pronuncia con cautela con argumentos esgrimidos a favor, en ciertos casos, del empleo de la mediación penal entre víctima y agresor en la violencia de género.

30 En igual sentido, Launay y Murray (1989: 113-131), quienes defienden lo que llaman la "mediación grupal". No existen, por el contrario, pronunciamientos que nieguen esta posibilidad.

31 En estos casos las dificultades no están tanto en la viabilidad de la mediación como en su resultado (acuerdo reparatorio). A ello se opone Domenig (2008: 302), si bien Laue (1999: 152-153) considera que en estos casos cabe hablar de una posible "reparación simbólica" a la "víctima colectiva". 
te van a tener consecuencias en el proceso penal, lo que no es óbice a su posible viabilidad con matices (Barona, 2011: 312). Igualmente, no observamos dificultades para las personas jurídicas-víctimas, en cuanto tienen acceso a otros instrumentos de justicia reparadora, de manera que, cumpliendo con las reglas procesales de representación, tienen capacidad de intervención y eficacia en un instrumento como es el de la mediación penal (Barona, 2014a: 106-107)..$^{32}$

Por su parte y con relación a los presuntos victimarios, las reticencias también existen, dado que podemos considerar a priori excluibles de mediación a los reincidentes (porque podrían "abusar" de la mediación penal), ${ }^{33}$ a los terroristas, a los violentos, etcétera, en suma, aquellos victimarios que por las características de los hechos que se les imputan podrían hallarse estrechamente vinculados con delitos más graves, lo que llevaría a excluirles de plano de la mediación. Consideramos, empero, que ante una regla general podría considerarse la excepcionalidad. Un ejemplo de esta excepcionalidad, aun cuando no pueda considerarse propiamente mediación penal, pero sí encuentros restaurativos, fueron los que se llevaron a cabo mediante el denominado "Proyecto Nanclares" porque se realizó en la cárcel Nanclares de Oca, en España, entre condenados por acciones de la banda terrorista ETA y sus víctimas. ${ }^{34}$ En estos casos los encuentros pretendían restaurar personalmente, moralmente, empero carecían de consecuencias jurídicas o posibles beneficios penitenciarios, si bien sus resultados son tan estremecedores y esclarecedores que permiten, sin lugar a dudas, presentar un exponente de justicia reconstructiva que allende las consecuencias jurídico-penales que se mantienen, ofrece unas bondades innegables para quienes en ellos participaron. ${ }^{35}$

32 Y los mismos argumentos que permiten sostener su intervención como víctima en la mediación son viables cuando se trata del victimario, aun con el reconocimiento legal de la responsabilidad penal de las personas jurídicas en numerosos ordenamientos jurídicos.

33 En Alemania, tras la prohibición se ha producido la viabilidad con condiciones, estableciéndose caso por caso si pueden acudir a mediación penal aun cuando sean reincidentes, no aceptando - opinión que creo más conveniente- la exclusión cerrada apriorísticamente (Kilchling, 2008: 336).

34 Esta experiencia, sus principios y condicionantes, queda expuesta en la obra de quien la coordinó, Esther Pascual Rodríguez (2013). Para algunas consideraciones al respecto, véase Barona Vilar (2015: 223-235).

35 Estas experiencias desarrolladas en España no son únicas, sino que con carácter previo se desarrollaron en otros países. Basta pensar en los encuentros paramilitares católicos y protestantes de Irlanda del Norte y las víctimas. Interesante en el análisis de estos encuen- 


\section{ClLaSes DE MEDiación PENAL}

La mediación penal puede presentarse de forma diferente en atención a diversas variables que pueden concurrir. Vamos a referenciar las que de forma más palmaria encuentran desarrollo práctico, que son: mediación directa y mediación indirecta, mediación preprocesal, intraprocesal, y postsententiam.

Atendiendo al primero de los criterios, aquel que considera la manera en que se lleva a cabo la mediación penal es posible distinguir entre mediación directa y mediación indirecta (Pascual, 2008: 170-171).

1) Por un lado, la mediación directa se despliega con las dos partes hallándose simultáneamente en el mismo espacio físico. Lógicamente, la finalidad de la mediación se cumple en principio de forma más clara cuando las partes se pueden hallar simultáneamente face to face, trabajando con el mediador, y se alcanzan mayores cotas de acuerdos a través de este medio, debido a mayor potenciación del diálogo. Ello no es óbice, empero, a la posibilidad de realizar entrevistas individualizadas (caucus) con cada una de las partes, comenzando con la víctima y siguiendo con el víctimario, siendo en esta labor muy importante la actividad que despliega de forma habilidosa el mediador. Se le llama face to face mediation, victim-offender-mediation (Kurki, 2003: 294-297), o en Alemania y Austria, Täter-OpferAusgleich.

En los países anglosajones las variables de estas modalidades son grandes. Así, se habla de la denominada face-to-face conferences of victims, offenders and stakeholders, que es un procedimiento en el que las partes pueden plantear un acuerdo, pero siempre desde la concreción de las posibles consecuencias que el crimen ha tenido en la realidad social y personal, y, por supuesto, sus posibles implicaciones en el futuro. Es la manifestación más intensa y personal de justicia restaurativa, si bien está especialmente indicada para determinados supuestos y todos ellos de naturaleza individual; por ejemplo, para conflictos escolares en Australia, Canadá (Sherman y Strang, 2008: 54) e Inglaterra (Shapland, 2004: 197).

tros es la obra de Eriksson (2009), en la que se expone el itinerario para alcanzarlos y las dificultades que arrastraron. 
2) Por otro lado, la mediación indirecta discurre de manera sucesiva, no simultánea, con el mediador y las partes, de modo que no se da "cara a cara" entre ellas, y no coinciden físicamente en el mismo espacio la víctima y el victimario. La técnica de mediación en estos casos es diversa a la anterior, en cuanto las habilidades del mediador irán dirigidas a convertirse en vehículo de transmisión de información de una parte a otra. Se ha venido considerando que esta modalidad de mediación no es tan eficaz como la directa, si bien es indudable que, en determinados casos, a saber, por la naturaleza del hecho, puede ser conveniente que no exista el cara a cara entre la víctima y el presunto victimario, por lo que se emplean medios intermedios tales como cartas explicativas o petición de perdón, en su caso.

Exponentes de esta modalidad pueden encontrarse en el sistema common law (Sherman y Strang, 2005: 13 y 32), tales como: shuttle communication o shuttle diplomacy mediation, vía indirecta de comunicación entre los delincuentes y sus víctimas, a través de su intermediario, que puede serlo un mediador o un facilitador, y que puede mantener una relación a través de teléfono, de mensajes en ordenador o en móvil, etcétera. En este procedimiento de comunicación no existe el face-to-face y permite que, en determinados hechos delictivos, se evite la violencia que comporta el volverse a enfrentar ambos de manera directa. Por su parte, la victim-absent discussions with offender and supporters about crime $\mathrm{u}$ offender-absent discussions with victim and supporters about crime, son dos formas de comunicación unilateral, en las que bien es posible que exista facilitador o persona interpuesta, que puede ser un mediador, quien actúa en ausencia de la víctima, o bien que la comunicación se mantenga tan solo con la víctima, hallándose ausente el delincuente. Otra vía es la denominada court-ordered restitution, con una naturaleza más imperativa, muy eficaz en el ámbito de la delincuencia penal juvenil. En todas ellas pueden o no intervenir terceros que colaboren más o menos en la búsqueda de la solución y la aplicación de la justicia reparadora, de manera que en ciertos casos se habla de mediador y en otros, de facilitador. En los modelos de conferences programmes lo más común es que intervenga un facilitador, que no mediador, siendo aquel el que se hace responsable de procurar un foro en el que sean las partes las que ellas mismas, y por sí mismas, llevarán a cabo la 
negociación, en su caso. El papel del facilitador es asegurar que las partes se centren en las razones de su encuentro y mantengan de forma civilizada su comunicación, si bien el facilitador no espera participar ni liderar la discusión (Sherman y Strang, 2008: 33). Podría ser útil para procesos colectivos como las estafas en escala en la que muchos son los ofendidos, o en los macroprocesos que cuentan con un número importante de víctimas en el proceso.

Atendiendo a otro criterio diverso para la configuración de la mediación penal, a saber, en atención al momento en que se desarrolla la posible vinculación con el proceso penal, podemos diferenciar entre mediación preprocesal, intraprocesal y postsententiam: ${ }^{36}$

1) Si la mediación se desarrolla de forma anticipada al proceso (preprocesal) viene a desempeñar una función de verdadera alternativa y, por ende, excluyente del proceso penal cuando existiere acuerdo entre los sujetos intervinientes (Barona, 2011: 319). Solo entendemos posible esta modalidad alternativa de la mediación penal en el delito de calumnia e injuria contra particulares y en los delitos perseguibles solo a instancia de parte. En este caso, de ser posible, habría que regular el valor del acuerdo y cómo otorgarle eficacia procesal.

2) La segunda modalidad es la mediación intraprocesal, que se vincula a un proceso pendiente y, como tal, los resultados que se alcancen en mediación van a incidir en el proceso mismo, siendo las consecuencias jurídicas diversas según la fase procesal en la que se desarrolle y culmine la mediación, y pueden ir desde el sobreseimiento

36 Hemos venido proponiendo y defendiendo esta tercera clasificación en atención a la relación con el proceso penal, con la trilogía conceptual que a nuestro parecer ofrece el mejor entendimiento. Así, los hemos incorporado a nuestros trabajos sobre mediación, entre otros, Barona (2009b: 105-106; 2011: 319-349; 2013: 478-479). Y lo hemos hecho frente a la vaguedad que venía sosteniendo la doctrina que, o bien no ha citado explícitamente las clases de mediación penal (Manzanares, 2007; Gordillo, 2007), bien ha trabajado directamente la mediación penal en atención a las diversas fases del proceso penal -instrucción, enjuiciamiento y ejecución de la sentencia- (Ríos, 2006: 49-70); o bien ha diferenciado entre dos modalidades, la preprocesal - concepto que también empleamos - y la mediación en las fases de investigación, intermedia y juicio oral (González, 2009: 43-49). A nuestro parecer, hacer referencia a mediación preprocesal, mediación intraprocesal y mediación postsententiam clarifican la relación de la mediación penal con el proceso penal. 
hasta la sentencia de conformidad, implicando en cualquier caso una terminación anticipada provisional, hasta tanto en cuanto se cumpla con lo dispuesto en el acuerdo. ${ }^{37}$

3) La tercera modalidad sería la denominada por nosotros mediación postsententiam. En esta modalidad podríamos hacer referencia a dos supuestos concretos: uno vinculado al proceso de ejecución, y el otro, al régimen disciplinario sancionador penitenciario. El primero, hasta el momento absolutamente desconocido, podría recoger la posibilidad de que, dictada una sentencia de condena, pudiera tener cabida una mediación con la víctima, siempre que una norma así lo habilitare. Cabría llegar a una reparación de la víctima y, a cambio, obtener la suspensión de la pena o a una sustitución de la pena privativa de libertad por otra. El acuerdo en mediación deberá surtir efectos en la ejecución, lo que solo podrá llevarse a cabo mediante un auto en la que se aplique o no el citado acuerdo a efectos de ejecución. ${ }^{38} \mathrm{El}$ segundo serviría para solventar conflictos en la "vida penitenciaria", estrechamente vinculada al régimen disciplinario sancionador. ${ }^{39}$ La mediación penal no solo puede llevar a buscar una solución postconflicto, sino que en sede penitenciaria se puede convertir, sin lugar a dudas, en un modelo que, favoreciera la reducción de violencias dentro del ámbito penitenciario a través del aprendizaje de actitudes de respeto, escucha, diálogo y tolerancia. En suma, un cauce innovador en el sistema sancionador penitenciario.

\section{CONGLUSIONES}

Es indudable que, frente al diagnóstico de una sociedad con paranoia por la seguridad, por el control, por la securitization, en la que cada vez hay más

37 Los efectos jurídicos que puedan derivarse de la mediación penal vendrán condicionados a la fase del proceso penal en el que se lleve a cabo la mediación. Por todos, Ríos Martín (2006: 49-70).

38 En todo caso, hasta el momento es más una propuesta que una realidad en España, mientras no se incorpore como posible en las normas jurídicas (procesales, penales y penitenciarias).

39 Véase Ríos Martín (2006: 68-71) quien se ha mostrado defensor de esta modalidad y ha dirigido proyectos de mediación penitenciaria.

Esta obra está bajo una Licencia Creative Commons

Atribución-NoComercial-SinDerivar 4.0 Internacional, IIJ-UNAM.

Boletín Mexicano de Derecho Comparado, núm. 155, mayo-agosto de 2019, pp. 685-720. 
penal y cada vez menos proceso penal y, por ende, menos garantías, surge una corriente denominada justicia restaurativa, que emerge con gran fuerza en la mayor parte de los países, incorporando servicios restaurativos, sistemas de mediación penal, que comportan una "mirada" distinta de los hechos delictivos, de las consecuencias jurídico-penales, de la furia "preventiva", de las presuntas víctimas y de los presuntos victimarios. Es un modelo que permite ineludiblemente "volver" a las personas, como eje de protección del derecho. Comporta abrir la puerta a la comunicación, al diálogo, al reconocimiento del otro (bilateral), a la búsqueda de la integración y no la disgregación.

La mediación penal se hace un lugar en el modelo penal y procesal penal. No es ella la justicia restaurativa, sino el instrumento, el procedimiento, en el que un tercero llamado mediador va a trabajar con las partes, facilitando el diálogo y, en su caso, y tras una serie de actuaciones desplegadas en las fases del procedimiento de mediación, puede obtenerse esa justicia restaurativa que cumple una triple función: de reparación a las víctimas, de resocialización de los victimarios, y de la prevención y control social que favorece a la sociedad en su conjunto. $\mathrm{O}$, si cabe, se desarrollan la función preventiva, resocializadora y reparadora. Ahora bien, es un modelo claramente complementario al proceso penal, no sustitutivo del mismo.

La realidad de la mediación penal se muestra palpable. En algunos países a través de proyectos piloto, en otros mediante una regulación ad extensum de la mediación, los mediadores, el procedimiento, los efectos y enlaces con el proceso, etcétera; en otros más, se admite la mediación, pero queda todavía algún recorrido para conformar un régimen jurídico estable. No cabe duda alguna que la mediación penal ha llegado para quedarse en el siglo XXI.

Es indudable que, frente al diagnóstico de una sociedad descreída, con la economía como elemento inspirador, con falta de asideros, vacua, desmotivada y desilusionada, con cada vez más desigualdad, más ansiedad, más suicidios, más depresión, más criminalidad y más miedo, la mediación penal - que puede hasta servir a estos fines de eficacia de la justicia penal en su conjunto - permite "volver" a las personas, como eje de protección del derecho, se convierte en una bocanada de aire fresco, la mirada desde las personas y con las personas. Solo por eso vale la pena hacerle espacio en el sistema penal, alimentando valores y principios que permitan construir una sociedad más justa, más equitativa, más solidaria y también más segura. 


\section{BIBLIOGRAFÍA}

Alessi, Giusseppe, 2001, Il proceso penale. Profilo storico, Roma, Laterza. APAP, Georges, 1990, "La conciliation pénale à Valence", Revue de Science Criminelle et de Droit Pénal Comparé, núm. 3.

BANNENBERG, Britta, 1993, Wiedergutmachung in der Strafrechtspraxis: Eine empirisch-kriminologische Untersuchung von Täter-Opfer-Ausgleichsprojekte in der Bundesrepublik Deutschland, Bonn, Forum Verlag Godesberg.

BARnetT, Randy E., 1977, "Restitution: a New Paradigm of Criminal Justice", Ethics.

BARONA VILAR, Silvia, 1999, Solución extrajurisdiccional de conflictos, Valencia, Tirant lo Blanch.

Barona VILAR, Silvia, 2004, Seguridad, celeridad y justicia penal, Valencia, Tirant lo Blanch.

BARONA VILAR, Silvia (dir.), 2009a, La mediación penal para adultos. Una realidad en los ordenamientos jurídicos (experiencias en España, EE UU, Gran Bretaña, países escandinavos, Francia, Alemania, Portugal, Brasily Chile), Valencia, Tirant lo Blanch.

BARONA VILAR, Silvia, 2009b, "Hacia la consagración de la mediación penal en nuestro ordenamiento jurídico y la recuperación de la justicia restaurativa", Pensamientos jurídicos y palabras, Valencia, Universidad de Valencia.

BARONA VILAR, Silvia, 201 1, Mediación penal. Fundamento, fines y régimen jurídico, Valencia, Tirant lo Blanch.

BARONA VILAR, Silvia, 2013, "Mediación penal como instrumento restaurativo de las víctimas: ¿en todo caso y para todas las víctimas?", en HoYOA, Montserrat de (dir.), Garantías y derechos de las víctimas especialmente vulnerables en el marco jurídico de la Unión Europea, Valencia, Tirant lo Blanch.

BARONA VILAR, Silvia, 2014a, "La persona jurídica como responsable penal, parte pasiva en el proceso penal y parte en la mediación penal en España”, en Ontiveros AlONSO, Miguel (coord.), La responsabilidad penal de las personas jurídicas, Valencia, Tirant lo Blanch.

BARONA VILAR, Silvia, 2014b, "Integración de la mediación en el moderno concepto de Access to Fustice. Luces y sombras en Europa", InDret.

BARONA VILAR, Silvia, 2015, "Del escepticismo al entusiasmo en mediación penal, de la restorative justice a la reconstructive justice (referencia especial al estatuto jurídico de la víctima y a los encuentros restaurativos víctimas-condenados por terrorismo)", en GómEz COLOMER, Juan Luis

Esta obra está bajo una Licencia Creative Commons

Atribución-NoComercial-SinDerivar 4.0 Internacional, IIJ-UNAM.

Boletín Mexicano de Derecho Comparado, núm. 155, mayo-agosto de 2019, pp. 685-720. 
(coord.), El proceso penal en la encrucïada. Homenaje al Dr. César Crisóstomo Barrientos Pellicer, vol. I, Valencia, Universitat Jaume I.

BARONA VILAR, Silvia, 2016, "Justicia integral y «Access to fustice»: crisis y evolución del paradigma", Mediación, arbitraje y jurisdicción en el actual paradigma de justicia, Valencia, Tirant lo Blanch.

Barona Vilar, Silvia, 2017a, Proceso penal desde la historia. Desde sus origenes hasta la sociedad global del miedo, Valencia, Tirant lo Blanch.

Barona Vilar, Silvia, 201 7b, "Justicia penal líquida", Revista Teoría y Derecho.

BARONA VILAR, Silvia, 2018, fusticia penal, globalización y digitalización, Santiago de Chile, Thomson Reuters.

Beck, Ulrich, 1999, World Risk Society, Cambridge, Polity Press.

BECK, Ulrich, 2004, "Wie global ist die Weltrisikogesellschaft?", Entgrenzung und Entscheidung, Frankfurt, Beck/Lau.

Bonss, Wolfgang, 1995, Von Risiko-Unsicherheit und Ungewissheit in der Moderne, Hamburgo, Hamburger Edition.

BRAithwaite, John, 2003, "Principles of Restorative Justice", en VON Hirsch, Andrew y RoberTs, Julian (eds.), Restorative fustice \& Criminal fustice. Competing or Reconciliable Paradigms?, Oxford-Portland, Hart Publishing.

Carnelutti, Francesco, 1946, "Cenerentola", Rivista di Diritto Processuale I.

Di CHIARA, Giuseppe, 2004, "Scenari processuali per l'intervento di mediazione: Una panoramica sulle fonti", Rivista Italiana di Diritto e Procedura Penale, núm. 2.

Domenig, Glaudio, 2008, Restaurative Fustice and Integrative Symbolik, Taschenbuch, Haupt.

Duff, Antony, 2001, Punishment, Communication and Community, Oxford, Oxford University Press.

DufF, Antony, 2004, "Restoration and Retribution", en VON HIRSH, Andrew y RoBerTs, Julian (eds.), Restorative fustice \& Criminal Justice. Competing or Reconciliable Paradigms?, Londres, Bloomsbury.

ERIKSSON, Anna, 2009, Justice in Transition. Community Restorative on Northern Ireland, Devon William Publishing.

Esquinas VAlverde, Patricia, 2008, Mediación entre víctima y agresor en la violencia de género, Valencia, Tirant lo Blanch.

ETXEBERRía GURIDI, José Francisco, 2009, "El modelo francés de mediación penal", en BARONA VILAR, Silvia (dir.), La mediación penal para adultos. Una realidad en los ordenamientos jurídicos, Valencia, Tirant lo Blanch. 
FatTaH, E. A., 1991, "From Crime Policy to Victim Policy. The Need for a Fundamental Policy Change", Annales Internationales de Criminologie, vol. 29, núm. 112.

FERRAJOLI, Luigi, 2016, Il paradigma garantista. Filosofia e critica del diritto penale, 2a. ed., Napoli, Editoriale Scientifica.

Gómez Colomer, Juan Luis, 2015, Estatuto jurídico de la víctima del delito. La posición jurídica de la víctima del delito ante la justicia penal. Un análisis basado en el derecho comparado en las grandes reformas españolas que se avecinan, Pamplona, Thomson Reuters Aranzadi.

GonZÁlez CANO, Isabel, 2009, "La mediación penal en España”, en BARONA VILAR, Silvia (dir.), La mediación penal para adultos. Una realidad en los ordenamientos jurídicos, Valencia, Tirant lo Blanch.

Habermas, Jürgen, 1991, El discurso filosófico de la modernidad, Madrid, Taurus.

Highton, Elena et al., 1998, Resolución alternativa de disputas y sistema penal, Buenos Aires, Ad Hoc.

Kilchling, Michael, 1995, Opferinteressen und Strafuerfolgung, Freiburg, Edition Iuscrim.

Kilchling, Michael, 2008, "Restorative Justice Developments in Germany", en Miers, David y AERsten, Ivo (eds.), Regulating Restorative Fustice. A comparative Study of Legislative Provisions in European Countries, Frankfurt, Cost.

KuHn, Thomas, 1962, Die Struktur Wissenschaftlischer Revolutionen, Frankfurt, Suhrkamp.

KURKI, Leena, 2003, "Evaluating Restorative Justice Practices", en VON HIRSH, Andrew y RoBerTs, Julian (eds.), Restorative fustice \& Criminal Justice. Competing or Reconciliable Paradigms?, Londres, Bloomsbury.

Laue, Christian, 1999, Symbolische Wiedergutmachung, Berlín, Duncker \& Humblot.

LAUnAY, G. y MURRAY, P., 1989, "Victim/Ofender Groups", en Wright, Martin y GalawaY, Burt (eds.), Mediation and Criminal Justice. Victims, offenders and community, Londres, Sage Publications.

MAIER, Julio B., 2009, "Estado democrático, derecho penal y procedimiento penal", ¿'Tiene futuro el derecho penal?, Buenos Aires, Ad Hoc.

MannozzI, Grazia, 2012, "Comentario a "Concessione della misura alternativa della semilibertà. La reintegrazione sociale del condannato tra rieducazione, riparazione ed empatía Tribunale di Sorveglianza di Venezia, Ordinanza 7 gennaio 2012, n. 5»”, Diritto Penale e Proceso, núm. 7.

Esta obra está bajo una Licencia Creative Commons

Atribución-NoComercial-SinDerivar 4.0 Internacional, IIJ-UNAM.

Boletín Mexicano de Derecho Comparado, núm. 155, mayo-agosto de 2019, pp. 685-720. 
ManZanares Samaniego, José Luis, 2007, Mediación, reparación y conciliación en el derecho penal, Granada, Comares.

Mbanzoulou, Paul, 2004, La médiation pénale, París, L'Harmattan.

NiLS, Christie et al., 1989, Abolicionismo penal, trad. de Alberto Ciafardini y Mirta Lilian Bondeza, Buenos Aires, Ad Hoc.

PASGUAl Rodríguez, Esther, 2008, "Fase de negociación en la mediación penal con adultos. El encuentro entre las dos partes: persona víctima y persona infractora. Técnicas de negociación. Mediación directa e indirecta", Estudios de Derecho Fudicial, núm. 136, "La mediación civil y penal. Un año de experiencia”, Madrid.

PASCUAL RODRÍGUEZ, Esther, 2013, Los ojos del otro. Encuentros restaurativos entre víctimas y exmiembros de ETA, Santander, Salterrae.

PASTOR, Daniel R., 2005, "La deriva neopunitivista de organismos y activistas como causa del desprestigio actual de los derechos humanos", Revista Furídica: Nueva Doctrina Penal.

RAKATOMAHANina, Volana et al., 2005, "Réflexions sur l'efficacité de la médiation pénale dans les violens conyugales faites aux femmes", $G a$ zette du Palais.

REUBER, S. y RÖSSNER, D., 2003, "Sammlung der Länderrichtlinien zum Täter-Opfer-Ausgleich mit einer vergleichenden Analyse", DBH-Materialien, núm. 49, Servicebüro für Täter-Opfer-Ausgleich und Konfliktschlichtung.

Reyes Mate, Manuel, 201 1, Tratado de la injusticia, Barcelona, Enthropos. Ríos MARTíN, Julián Carlos et al., 2006, La mediación penal y penitenciaria. Experiencias de diálogo en el sistema penal para la reducción de la violencia y el sufrimiento humano, Madrid, Colex.

RíOS MARTín, Julián Carlos et al., 2008, Fusticia restaurativa y mediación penal. Análisis de una experiencia (2005-2008). Estudios jurídicos, Madrid, Consejo General del Poder Judicial.

Ríos MARTín, Julián Carlos, 2016, La mediación penal, penitenciaria y encuentros restaurativos, Madrid, Universidad de Comillas.

Ríos MARTín, Julián Carlos, 2017, Justicia restaurativa y transicional en España y Chile, Granada, Comares.

SAlVIOLI, Giuseppe, 1969, Storia del diritto italiano. Vol. III. Storia della procedura civile e criminale, Firenze, Gozzini.

SHAPLAND, Joanna, 2004, "Restorative Justice and Criminal Justice: Just Responses to Crime?", en VON HIRSH, Andrew y ROBERTS, Julian (eds.), Restorative Fustice \& Criminal fustice, Oxford, Hart Publishing. 
Sherman, Lawrence W. y STRAng, Heather, 2007, Restorative Fustice: The Evidence, Londres, The Smith Institute.

SIEBER, Ulrich, 2006, "Grenzen des Strafrechts", Perpektiven der strafrechtlichen Forschung Amtswechsel am Freiburger Max-Planck-Institut fur auslandisches und internacionales Strafrecht, Albrecht/Sieber.

SIEBER, Ulrich, 2008, "Límites del derecho penal. Fundamentos y desafíos del nuevo programa de investigación jurídico-penal", Revista Penal, núm. 22.

Silva SÁnchez, Jesús M., 2011, La expansión del derecho penal, Madrid, Edisofer.

TAMARIT Sumalla, Josep María (coord.), 2005, “¿Hasta qué punto cabe pensar victimológicamente el sistema penal?”, Estudios de victimología: actas del I Congreso español de victimología, Lleida, Tirant lo Blanch.

Trankle, Stefanie, 2007, Im Schatten des Strafrechts, Berlín, Dunkers \& Humblot.

VARONA MARTínez, Gemma, 2009, Fusticia restaurativa a través de los servicios de mediación penal en Euskadi. Evaluación externa de su actividad (octubre 2008-septiembre 2009), Donostia San Sebastián, Universidad del País Vasco.

Zaffaroni, Eugenio Raúl, 2006, El enemigo en el derecho penal, México, Ediciones Coyoacán.

ZEHR, Howard, 1985, "Retributive Justice, Restorative Justice", New Perspectives on Crime and Justice, núm. 4.

ZEHr, Howard, 1990, Changing Lenses: A New Focus for Crime and Justice, Ontario, Herald Press.

ZEHR, Howard, 2002, The Little Book o Restorative fustice, Pennsylvania, Good Books. 